\title{
An activist religiosity? Exploring Christian support for the Occupy movement
}

Whilst Christian involvement in progressive social movements and activism is increasingly recognised, this literature has rarely gone beyond conceptualising religion as a resource to instead consider the ways in which individual activists may articulate their religious identity and how this intersects with the political. Based on ten in-depth interviews with Christian supporters of the Occupy movement, this study offers an opportunity to respond to this gap by exploring the rich meaning-making processes of these activists. The article suggests, firstly, that the location of the London Occupy camp outside St Paul's Cathedral was of central importance in bringing the Christian Occupiers' religiopolitical identities to the foreground, their Christianity being defined in opposition to that represented by St Paul's. The article then goes on to explore the religio-political meaning-making of the Christian Occupiers, and introduces the term "activist religiosity" as a way of understanding how religion and politics were articulated, and enacted, in similar ways. Indeed, religion and politics became considerably entangled and intertwined, rendering theoretical frameworks that conceptualise religion as a resource increasingly inappropriate. The features of this activist religiosity include: post-institutional identities; a dislike of categorisation; and, centrally, the notion of "doings" - a predominant focus upon engaged, active involvement.

Key words: Christianity, social movements, Occupy, activism, religious identity

\section{Setting the scene}

In the early hours of the morning on 28 February 2012, five people gathered to pray on the steps of St Paul's Cathedral. The eviction of the Occupy camp that had been located outside the Cathedral for over four months had begun shortly after midnight and only a few protestors remained. Amidst 
the chaos as police tried to remove this final group of protestors, the small group of people praying on the steps of St Paul's were instructed by the police that they too had to leave. "I'm a Christian. I'm praying on the steps of a church", one protestor ${ }^{1}$ responded, to which the police replied "the church don't want you here". On the protesters' subsequent refusal to leave, the police began to forcibly remove them. The protesters were dragged twice from the steps, returning to pray in between. As they were removed, one protestor recited the Lord's Prayer and another spoke some words of the seventeenth-century Digger Gerald Winstanley. At the bottom of the steps, the group began to pray again, until they were removed by the police for the final time. ${ }^{2}$ Who, then, were these "Christian Occupiers"?

The Occupy movement began in the United States when over a thousand people occupied Zuccotti Park in September 2011. Though Occupy garnered much journalistic attention and some scholarly work (cf. Halvorsen; Pickerill and Krinsky; Castells), there has been little academic exploration of Occupy's interaction with Christianity. This relationship takes on particular pertinence in the UK context, given that an Occupy camp was situated outside St Paul's Cathedral. This location led to an immediate and inevitable dialogue between the Occupiers and St Paul's, setting the scene for various interactions between the activist camp, the established church, and other forms of Christianity, including Christian support for the protest camp.

The Cathedral's reaction was initially positive. The Sunday morning following the camp's arrival, Giles Fraser, the Canon Chancellor, asked the police to leave the Cathedral steps, defending the right to peaceful protest. Between 21 and 26 October, however, the Cathedral management closed St Paul's due to health and safety fears and the Occupiers were asked to leave so that St Paul's could reopen. The Chapter of the Cathedral then voted to support legal action to remove the protestors, 
leading to the resignation, on 27 October, of Giles Fraser, who was concerned that there might be "violence in the name of the church" (qtd. in Butt et al.). The next day, St Paul's part-time chaplain Fraser Dyer also resigned, while Graeme Knowles, the Dean, resigned on 1 November, following the backlash against the Chapter's decision.

Meanwhile, a statement of Christian solidarity with the Occupy camp was disseminated online. Its signatories included such organisations as Christian Socialist Movement, Greenbelt Festival, London Catholic Worker and Student Christian Movement. The statement argued that "the global economic system...is based on idolatrous subservience to markets", contending that "we cannot worship both God and money" (Occupy LSX). The camp also received support from the national Quaker and United Reformed Church bodies. In addition, there were direct acts of Christian support, including the prayer described above that took place during the eviction. Another key event was the Sermon on the Steps, an interfaith service reflecting on love, peace and unity which took place on October 29. There were over a dozen Christian speakers at this service, including several clergy.

\section{Situating Christianity and Occupy}

Whilst the lack of attention given to the interactions between Christianity and Occupy may merely be a result of Occupy's relatively recent occurrence, it is also indicative of a more general trend, in which faith's role in left-wing politics and more progressive activism, whilst not neglected, has taken a marginal role compared both with studies of "secular" activism and an overwhelming focus on such phenomena as Islamism and the Christian Right (Wood 2). Smith, for example, asserts that “religion's important contribution to social movements remains conspicuously under-explored ... in the academic literature on social movements" (2), whilst Swarts highlights that "liberal congregations' involvement in left-of-centre organising has received far less attention than conservative religious activism" (xx-xxi). This deficiency is striking given the "long tradition of faithbased...critical campaigning and self-organisation in pursuit of social justice" (Dinham et al. 226). 
Several scholars have subsequently called for further attention to be granted to religion and spirituality's role in social movements (Kong; Poonamallee; Smith; Hutchison).

Attempts to address this, which have been more US- than UK-focused (cf. Hart; Smith), have furthermore predominantly conceptualised religion, in varying ways, as a resource. Firstly, there has been focus on the mobilising role of religious organisations, leaders and institutions. In the Christian context, this has led to stress upon religion at the congregational level (Wald et al.; Campbell; Brown and Brown; Hart; Smith). Emphasis has been placed upon the "ready-made, extensive recruitment networks and organisations" that religious leaders "have at their disposal" (Smith 15), alongside the financial support, meeting spaces and communication networks offered by churches (Williams "Beloved community" 248). Churches have also been identified as places of political and civic empowerment (Faver; Campbell; Brown and Brown). In reaction against this congregational focus, Todd suggests a shift towards examining regional and grassroots religious networking organisations, while Hutchison highlights the importance of informal religious networks (113).

Secondly, religion has been conceptualised as a provider of motivation and legitimation (cf. Williams, "Beloved community"), serving to provoke and sustain social movement participation and representing a "source of generative capacities for a community" (Poonamallee 258). Religion may create a sense of connectedness that spurs action (Faver 64) or provide courage to break the law through the rationale of obedience to a higher authority (Williams "Religious social movements", 317). Thirdly, religion has been theorised in terms of its provision of "symbolic and emotional resources" (Smith 11). Smith contends that "religion, as a major creator and custodian of powerful symbols, rituals, icons, narratives, songs, testimonies and oratory, is well-positioned to lend these sacred, expressive practices to the course of political activism" (ibid). Though these latter two 
conceptualisations of religion as a more personal and cultural resource are useful, many such theories share a fairly static conception of religion and religious identity, in which they are taken as givens, rather than being examined and problematised, an approach that this research hopes to advance.

The treatment of religion as a resource is linked to resource mobilisation theory, a branch of social movement theory, and it is worth considering briefly the problems associated with this approach more generally. The resource mobilisation paradigm considers the emergence of social movements in terms of the resources available that are perceived to facilitate them, and it is also characterised by a concern with social movement success and failure. However, Occupy does not lend itself particularly well to an analysis on such terms. As Pickerill and Krinsky assert, Occupy had an “official...refusal to make 'demands' that could be co-opted by existing political parties or that recognise the legitimacy of the state as an agent capable of or willing to implement policy" (283). It is thus difficult to assess Occupy in terms of traditional notions of outcomes and, in accordance with this, a vocabulary of success and failure was notably absent in the interviews conducted with Christian Occupiers. Instead, Occupy was an exercise in pre-figurative politics, modelling the world it wanted to see through such practices as reclaiming urban spaces for public use; deploying consensual and non-hierarchical decision-making; and opening up space for conversations and dialogue not permitted in traditional institutional spaces. The new social movement theorist Melucci's idea of social movements and activist activities as "laboratories" (208) usefully captures Occupy's essentially experimental nature. New social movement theory also provides a way to analyse social movements by asking different questions to those of resource mobilisation. Jasper, for example, urges that greater emphasis should be placed upon the "biographical dimension of protest" and how protesters "see their place in the world" $(214,11)$, and the approach I advance here similarly prioritises the meaning-making activities of social movement activists. 
As suggested above, there are also distinct problems though with treating religion as a resource. Firstly, this approach renders the fluidity and complexity of religion static and immutable, being considered alongside such factors as financial resources and buildings, or in relation to its provision of such things. This fails to take into account the varied ways in which religion is drawn upon by social movement participants and underplays the complexity of religio-political meaning-making. Secondly, to consider religion as a resource instrumentalises it, such that religion is considered predominantly as something beneficial or "useful" to social movement success. In this way, religion is rendered an external factor rather than being considered as something more intrinsic to social movement activism or with regards to its relationship to other factors such as political identity.

In order to problematise the role of religion, rather than rendering it a static given, it is thus important to consider Christianity and Occupy through the lens of literature on the UK's changing religious landscape. One of the most significant claims of contemporary religious studies is that we must not look only within institutions - e.g. churches - to find religion. Davie, for example, suggests that Britain is a place of "believing without belonging", in which people continue to believe but do not participate in religious institutions and look outside the churches for spiritual fulfilment $(2,37)$, while Ammerman contends that "religion is bigger than ... theological ideas and religious institutions" ("Observing", 6). Whilst this notion of belief outside the churches is useful for understanding the Christian Occupiers, the terms often used to describe non-institutional religion, such as privatised religion, invisible religion, implicit religion, popular religion, common religion, folk religion and civic/civil religion (Davie 74), are less so. The religion exhibited by the Christian Occupiers was neither particularly "invisible", being expressed in such actions as the eviction night prayer, nor "popular", being very specifically politically-informed and -engaged. 
Another important concept is Heelas and Woodhead's "spiritual revolution", which asserts that there has been a "turn away from life lived in terms of external or 'objective' roles, duties and obligations and a turn towards life lived by reference to one's own subjective experiences" (2). Though Heelas and Woodhead found very little overlap between the "congregational domain" and an "invisible' holistic milieu" in Kendal, the religion exhibited by the Christian Occupiers does not fully fit in either category. A real strength of their approach, however, is its stress that the spiritual revolution does not necessarily equate to individualisation, but may instead involve the "self-inrelation" $(8,11)$. This is a helpful challenge to overly-individualistic conceptions of religion as consumerist, privatised (Luckmann 127) or a form of "seeker spirituality" (Wuthnow qtd. in Fuller 154). Such ideas may fail to do justice to the sincerity with which people seek spiritual meaning (Lyon) and fail to account for expressions of religion that may be publicly expressed and motivate political action, despite not taking an institutional form. The intersections of political and religious identity, however, remain underexplored in the literature and an exploration of Christianity and Occupy offered a significant opportunity to consider this through an empirical case-study.

\section{Methodology}

This research involved interviews with ten Christian Occupiers, whom I found and contacted through social media and snowballing. Semi-structured interviews were used in order to provide an "indepth elucidation" (Bryman 50) of this particular case of Christian involvement in progressive activism, and to allow sufficient openness to explore new and emerging themes (Knight). I hoped accordingly to let findings "'emerge' from the data, rather than deciding a priori what will be important and setting out to find that" (Burningham and Thrush 192) and, following Wuthnow, to become aware of the Christian Occupiers' vocabularies, rather than pushing upon them external definitions and ideas (246). Data was analysed through searching for key themes, and then categorising these further into sub-themes and significant patterns. 
This project provoked difficulties regarding anonymity. Several interviewees had been involved in high-profile public actions, such as the eviction-night prayer, following which they had been named in the press. Others had written or spoken extensively and publically about their experiences of Occupy. It seemed possible therefore that the interviewees, even if anonymised, might be identifiable. Alongside these pragmatic difficulties, I also wanted to give my interviewees the opportunity to take ownership of their views, rather than being eclipsed by anonymity.

Furthermore, in a social media society, in which opinions are increasingly voiced and discussed in a whole arena of online public spaces, it seems likely that anonymity may be a diminishing concern. Interviewees were thus given the choice as to whether or not they wanted to be named. All but one chose to be named, either fully or by their first name, confirming that academic norms of anonymity may not reflect societal changes or always be the desire of research participants.

\section{The Christian Occupiers}

The term "Christian Occupiers" is not unproblematic. Though all interviewees responded to the call for Christians involved in Occupy, their uses of, and relations to, the term "Christian" were highly varied and complex, including disinclination to use the term to describe their faith. I use the term here partly due to the difficulties posed by the challenge of finding alternative terminology, but partly because Christianity remains the religious tradition (or one of several) in which the interviewees can be located, even if Christian self-identification was problematic. The exploration of Christian self-identification below, however, cautions against simple assumptions of what constitutes Christianity.

The term "Occupiers" also has difficulties, given the interviewees' varied levels of involvement in Occupy, ranging from long-term, sustained participation to intermittent involvement. Here, 
"Occupier" is used as shorthand for someone that both supported Occupy and was sometimes physically present at the camp and involved in some capacity. It also seemed inappropriate to divide activists into those considered "proper Occupiers" and those not. This decision corresponds with Occupy's non-hierarchical spirit, and was influenced by the concern voiced by some interviewees regarding the problematic emergence of divisive labels during their experience of Occupy, such as "non-campers" and "campers". In addition, the Christian Occupiers do not represent a unified single group, but individuals with varying interpersonal relationships and connections.

The interviews were with the following individuals: $\mathrm{Amy}^{3}$, Ash Ghinn, George Barda, Holly, Joe Thompson, Kevin Snyman, Sam Walton, Siobhan Grimes, Symon Hill, and Tanya Paton ${ }^{4}$. The interviewees ranged in age from early twenties to late fifties, the most notable clustering being that four interviewees (Holly, Joe, Sam and Siobhan) were in their twenties. Eight had high levels of formal education, including at least a first degree. All interviewees had been involved in the St Paul's Occupy camp, except Joe and Ash, who were involved in Sheffield, and Amy, who was involved in both Edinburgh and London. ${ }^{5}$

\section{St Paul's: a site for the negotiation of Christianity}

The location of the Occupy camp outside St Paul's is significant for a number of reasons. The Christian Occupiers expressed much anger and sadness at St Paul's confused and sometimes antagonistic response to the Occupy camp and this led to two specific trends: firstly, declaring St Paul's to be spiritually bankrupt and taking spiritual lessons from the Occupy camp; and secondly, seizing opportunities for Christian representation and witness. The specific location of the London Occupy camp thus led to a perhaps unusual opportunity, within a social movement context, to negotiate the terms of Christianity, and who could and should represent it. 


\section{Spiritual bankruptcy, spiritual lessons- perceptions of St Paul's and Occupy}

Anger at St Paul's "blatantly deceitful" and "disgusting" actions stemmed from frustration at the Cathedral's lack of concrete support for the Occupy camp and the limited opportunities for dialogue. As Sam expressed, “St Paul's weren't particularly keen on dialogue. [That] would be an understatement. They were as unresponsive as a wall frankly". There was also suspicion that the Cathedral was complicit with the police. This was particularly evident in accounts of St Paul's staff watching as protestors were removed from the steps during the eviction-night prayer. Sam commented "there were people watching from the balcony above the doors of St Paul's the whole evening", while Siobhan recalled "there were these massive doors and they're locked and they're up there and they're watching on". Such experiences also led to a sense that St Paul's had missed an opportunity to demonstrate "a compassionate ministry, a loving ministry" (George). As Siobhan also highlighted, "it could have been such a brilliant opportunity for the church to really live out what they say they believe".

This led to a significant discourse, in which St Paul's was considered to be spiritually bankrupt or "unchristian". Tanya, for example, considered that "the Christian thing would have been to actually open their doors and embrace the Occupiers", while Sam expressed the following:

I'm happy to say they lied ... which is worse than the City of London in fact, because the City of London at least was honest that it was trying to evict people. St Paul's were lower than that and I think that just goes to show that they have absolutely no Christian principles in them...It's a building but there is no God

Within this discourse, St Paul's also became strongly associated with money and power. As Holly expressed, "the church almost seemed to represent the City and the wealth of the City". Similarly, Sam and Kevin described St Paul's as having become a "Church to Mammon" and a "Church of the 
Corporation of London", respectively. Sam continued that "the church is part of the state and will act part of the establishment and has frankly no interest in Jesus' message", while George highlighted how "the high priests of today were in not dissimilar positions to the high priests of yesteryear, namely siding with power". Such views confirm several scholars' assertions that established and institutional forms of Christianity are increasingly regarded as inauthentic (Drane 4; Flory and Miller 36), thus mirroring a broader contemporary concern with authenticity (Taylor).

The Christian Occupiers instead drew spiritual inspiration from the Occupy camp. Firstly, the similarities of Occupy's aims and the Christian message were stressed. George highlighted how Occupy was "about prefiguring a world- a Christian world basically...about sharing, giving everything away and loving your enemy", while Siobhan also regarded the Occupiers as "trying to bring about things that are quite similar to gospel messages". Secondly, the inclusivity of the camp was highlighted as an embodiment of Christian values. Sam, for example, identified Occupy's care for the homeless and those struggling with addictions, contrasting this with the fact that St Paul's cared "fuck all about them". Thirdly, Occupy was seen to provide lessons for the church. Siobhan asserted that Occupy's attempts to deal with problems resulting from its desire to be inclusive represented a model for church:

If you're going to be a welcoming community ... representing people that are massively disenfranchised and disempowered, then you are going to attract people who are abusive and all of these things and I think that's something to be really proud of...Dealing with it can be problematic, but I think it's a really good model of what church should be.

Kevin also wanted Occupy to "speak" to the church, blurring ideas of "sacred" and "secular" and challenging traditional notions of who speaks for Christianity. 


\section{Activism with a "Christian flavour" - Christian representation and witness}

The Christian Occupiers also responded to St Paul's by embodying alternative visions of Christianity. Occupy's location outside St Paul's meant that much of the Christian Occupiers' participation took on a distinctly "Christian flavour". Tanya was part of the Occupy-St Paul's liaison group and helped organise the Sermon on the Steps, while Kevin, alongside speaking at this event, promoted support for Occupy within the United Reformed Church. George, Siobhan, Sam and Symon were all involved in the eviction-night prayer and represent four of the five or six ${ }^{6}$ people that took part. Both George and Tanya were part of Occupy Faith, a group formed to "shine a prophetic light on the collusion of establishment religious bodies with power and corrosive political influence" (Occupy Faith), while Siobhan and Symon were members of Christianity Uncut, a group that opposes austerity and that was fairly embryonic at the start of Occupy London.

The specific location of the Occupy camp outside St Paul's thus became centrally important for activists of religious faith, bringing issues of religio-political identity to the fore in more explicit ways than might be expected. Several interviewees confirmed that there was a deliberate attempt to embody alternative representations of Christianity to the one offered by St Paul's. George, for example, stated that "more progressive Christians saw Occupy as an opportunity really to stand up for the kind of Christianity they believed in, rather than the dominant conception". Sam highlighted too how “when St Paul's were being awful there was clearly a role to say that, as Christians, this isn't what it's about", thus implying an expression of a different, and, by implication, more authentic, Christianity. Occupy, by virtue of its presence outside St Paul's, thus became a site of redefinition, in which different visions of Christianity were articulated. Siobhan, who tied herself to the pulpit of St Paul's during a service after the eviction, commented: 
I think it was a matter of 'Christianity had a whole other face', not that we wanted to be the face of Christianity, but there's a whole different kind of Christianity that isn't about refusing to speak to people.

This confirms Edles' assertion that each "brand" of Christianity "sets out to influence the symbolic content of Christianity in the public sphere; they seek to define what Christianity is, and assert who the 'authentic' Christians are and what 'authentic' Christians say and do" (2013: 10).

A key example of influencing Christianity's symbolic value in the public sphere is represented by the eviction-night prayer action. Siobhan drew positive attention to their presence there as Christians who "weren't necessarily looking really pious, but were just around...offering some sort of comfort", while Symon stressed how "people kept coming over and thanking us for praying and these weren't Christians ... they were just pleased we were there". Symon continued that, for him, this represented a form of alternative evangelism:

Those people...got a far better impression of Christ and Christianity than they ever would have done from somebody standing on a street corner waving a Bible... I believe in evangelism but I believe evangelism is living out the Gospel. It's not just about converting individuals.

This exhibits a correspondence with post-Christendom thought, which understands mission to mean not just "saving souls", but social action, advocacy, and campaigning (Murray 239).

\section{An activist religiosity?}

The emphasis in the quotation above on "living out the Gospel" also demonstrates a prioritisation of "doings" over "sayings", which emerges as a predominant theme in what I have defined as an activist religiosity. Too often, as discussed above, religion has been understood merely as a 
motivational and institutional resource for activism, in ways that ignore the complexity of religion and fail to take into account the very rich meaning-making activities of religiously-inspired political activists. In the meaning-making processes of the Christian Occupiers, similar ways of understanding both religion and politics were strikingly present, to the extent that religion and politics became almost indistinguishable. The term "activist religiosity" thus hopes to capture the centrality of both activist politics and religion, neither taking primacy over the other. There are several main characteristics of this "activist religiosity": post-institutional identity; dislike of labels; and, most significantly, the prioritisation of "doings" over "sayings". In exploring this integration of the religious and the political, I thus hope to move away from resource-based accounts, in which religion emerges, somewhat reductively, as merely a "useful" collection of resources for activist activity. For the sake of both clarity and emphasising the similarities, I discuss various aspects of religious and political identity separately here. However, within the interviews, this was much "messier", religion and politics being considerably entangled.

\section{Post-institutional identity}

Virtually none of the Christian Occupiers expressed party political identification. The only party mentioned positively was the Green Party, the small size of which was lamented by George. Siobhan also, almost reluctantly, identified with the Green Party, as she didn't feel "cool enough" to be a Christian anarchist. This vague party affiliation was the most concrete party politics expressed by any interviewee. More common was a dislike of party politics. Tanya, for example, commented "I think party politics should be thrown out", while George argued that political parties failed to offer any "programmatic alternative". However, the Christian Occupiers did not just exhibit an antiinstitutional stance. The term post-institutional is important because it suggests alternative models of doing politics that go beyond institutions. Occupy itself should be understood in this light, as an experiment in post-institutional politics. 
Corresponding with this post-institutional political identity, there were also several expressions of post-institutional Christian identity. While half the interviewees attended church regularly, half did not attend, or had not attended for some time. This conventional model of Christian behaviour and belonging was rejected in favour of alternative conceptualisations of church. Tanya, referencing the Biblical passage of "where two or three are gathered together in my name" (Matt. 18.20), asserted that, whether "at home, in the fields, in mountains, in a desert", if people are "invoking God in terms of the conversation, that's it- that's a church". Holly, who ceased attending church upon joining the SPEAK Network team, reflected that "I see SPEAK as my church at the moment", commenting further that "when I meet up with my friends, we talk about that stuff anyway". Ash also had a small friendship-based faith community, consisting of him, his wife and another couple:

They both call themselves Christians and they are really good for me and I think I'm good for them...There's a real strong bond there of mutual respect and values...So I think that's my faith community- it's really just through those two...as real strong weekly connection.

These findings provide examples of "post-institutional modes of sociality" (Engelke 60), serving to challenge the congregational focus of much work on religion in social movements. Davie's conception of "believing without belonging" is useful in acknowledging belief outside of church walls. However, it doesn't account for these small, self-created forms of religious belonging. Jamieson, writing from a Christian perspective, has identified many such "post-church" groups (118) and there is thus need to further explore informal expressions of Christian belonging that have "escaped" from their "modernist incarceration in a distinct religious sphere" (Szerszynski 38).

There was also opposition to organised religion. Symon, for example, hoped for a "grassroots" Christian movement, while Tanya considered organised religion to be a "form of brainwashing". Implicit throughout this discourse was the idea of an "authentic" Christianity (Edles), offering truth 
not expressed by institutionalised Christianity, but not completely destroyed by it either. In addition, both church-going and non-church-going Christian Occupiers stressed the importance of their own internal experiences, rather than external authorities such as religious institutions, in determining their faith. Tanya, for example, commented that she tended "to follow my own heart and my head in terms of what I believe", while Symon quoted affirmatively the words of Gerald Winstanley: “'every man...was made to be teacher and ruler over himself that he needs not run abroad for any teacher and ruler without him'". George also conceptualised experiences of the divine as "self-revealing", commenting on "what God has shown herself to be... in my heart". This provides evidence for Heelas and Woodhead's conception of the "subjective life", which seeks direction not from external authority but from inner sources of significance (4). The Christian Occupiers, however, do not fit into the "holistic milieu" any more than they do the "congregational domain" (Heelas and Woodhead), suggesting the need for alternative terminology to theorise this form of politicised religious identity.

\section{Dislike of labels}

There was also ambiguity of political identity and a disinclination to be categorised. Joe, for example, commented: “I don't want to put myself anywhere. I'd like to engage with people on a level which is free from [whichever] political talk or spectrum you want to affiliate with". Holly also felt that it was difficult to categorise herself politically and stated that she was "still exploring". These political identifications confirm Chatterton's perspective that contemporary activists tend to embody complex, messy and multiple political identities, including a reluctance to be defined (1210; see also Juris 86). Labels that were used were typically vague, such as Siobhan's "disorganised left" and Holly's "left-wing".

This dislike of labels also featured in discussion around Christian self-identification, which included a strong disinclination to use the term Christian. Ash and Joe both found it difficult to self-identify as 
Christian due to a fear of being boxed in or categorised. Ash articulated how belief required "a lot of unwrapping" and that he did not want to be judged "on what religion I claim to belong to". He therefore avoided calling himself a Christian, preferring his faith to be revealed "naturally" in a "much more organic" fashion. Joe also stated that he would "typically probably not" self-identity with the "loaded term" of Christian:

I think nowadays I'd probably say I wouldn't call myself a Christian and I almost feel guilty about that but...I want to be able to have room to articulate whoever the hell I am to people...I don't want to have these rigid codes to apply...I don't want them to make assumptions which aren't true of me.

Despite distancing themselves from the term Christian, however, both Ash and Joe placed great emphasis upon Jesus. Ash stated he was "happy to talk about Jesus any time, because I think he's the key", while Joe asserted "I'll happily talk to people - anyone - about my faith and my relationship with Jesus". Siobhan similarly identified more positively as a "Jesus follower" than a Christian, her difficulty with the latter term being grounded in negative things done in Christianity's name, such as "Christians who baptise bombs and say things about people that are gay that are totally unacceptable", making this disinclination to use the term "Christian" inherently political. In Post-Christendom, Murray suggests that the adoption of "Jesus follower" as a term of identity is an increasingly-observed trend (308). However, this form of religious identity has been little explored in the academic literature, marking a current gap in understanding.

As well as this corresponding dislike of both religious and political labels, there were also attempts to use the term Christian in ways which served to destabilise it as a label. This cautions against taking the term "Christian" for granted, demonstrating its multiple, complex and negotiated uses. Both Holly and Symon in particular self-identified as Christian in ways that served to reclaim and redefine 
the term. Holly felt challenged to try "to go against the stereotype that everyone has", expressing her stance as "I'm a Christian, but being a Christian doesn't mean $X, Y, Z$ ". Symon also reclaimed the term, but by stressing his right to it:

I'm as much as a Christian - I'm as entitled to that word as much - as the Bishop of London or whoever. If there are Christians I strongly disagree with, why should they have all the words? They're my words too.

This corresponds with Edles' observation that progressive Christians may be "unwilling to cede Christianity to conservatives" (6). George and Amy's religious self-identifications also reclaimed the term from conservative associations. George, for example, identified as a "Christian-Buddhist", while Amy self-described as a "Christian-hippy-anarchist". The hyphenated nature (Harris 53) of these religious identities serve, similarly to Holly's "I'm a Christian but", to disrupt stereotypes and assumptions as to the meaning of "Christian", representing an active unsettling of the set of meanings that might be associated with a particular identity label.

Several interviewees also opposed denominational labels. Symon, for example, "quite deliberately didn't" identify with any denomination, considering them "a relic of Christendom", while Holly also commented "I don't have a denomination". Similar dislike was expressed for terms like "evangelical" and "liberal". Symon hoped that he didn't "easily fit" into such categories, while Joe asserted "I really hate those spectrums". Where there was denominational affiliation it was typically fluid, corresponding with Lyon's observations on the lightness of twenty-first century denominational identity (48). Siobhan, for example, attended an Anglican church, but considered her preferred "brand" of Christianity, in a process of what might be thought of as imagined religious belonging, to be Anabaptist. 


\section{Focus on doings}

Most significantly, the Christian Occupiers demonstrated a considerable focus on "doings". Several interviewees, for example, expressed their politics through lifestyle practices that embodied a politically alternative set of values. Ash, for example, opposed monetary exchange, explaining "I don't want to do anything for money- [I haven't] for the last seven years, because it feels contractual. I do take gifts". As well as not taking paid employment, Ash was thus involved in "skipping", whereby food is "salvaged" from supermarket bins, an activity that George and Joe also practiced. For Ash, this way of life facilitated human interdependency and interconnections, imbuing such practices with spiritual significance. Hitchhiking, for example, reminded Ash that "people do like to care", while accumulating material possessions was seen to keep people "immune from recognising need". Squatting also featured as an alternative lifestyle choice. George lived in a squat, working as much as was needed to sustain his activism, while Amy had spent three years living at an anti-roads protest camp. This demonstrates the existence of "activist lifestyles", in which lifestyle choices reflect political values or are deployed to facilitate further activism. This confirms Melucci's contention that "movements live in another dimension: in the everyday network of social relations...and in the attempt to practice alternative lifestyles", demonstrating "complementarity between private life, in which new meanings are directly produced and experienced, and publicly expressed commitments" (1989: 71, 206). Thus, everyday life is politicised (Hetherington 1998; Haenfler et al. 2012).

As well as this politicisation of everyday life, the politics expressed by the Christian Occupiers also prioritised action over more conventional modes of political engagement. This is hardly surprising given the activism they were involved in but is mirrored by a central, though implicit, focus upon "doings" within their religious discourses. While conceptions of Jesus varied from "the Son of God" who died "on the cross for us" to a "highly unorthodox teacher who basically taught his followers to live fearlessly", all interviewees strongly stressed Jesus' life and actions. Holly, for example, stated: 
"he talked about giving money to the poor and he just walked around being amongst the people", while Tanya emphasised that Jesus "had no home of his own ...walked around barefoot...[and] basically relied on the charity and kindness of strangers to look after him". Sam also commented on Jesus "upsetting the tables in the temple", while Symon referenced "Jesus standing with the marginalised". The prevalence of verbs in these accounts demonstrates the focus upon "doings", an emphasis which politicises the figure of Jesus, who becomes, as Holly expressed, a "huge revolutionary".

The Christian Occupiers also stressed their religious duty to, as Sam expressed, to "create the Kingdom of God". This demonstrates a view of the Kingdom as something not just to be awaited, but to be actively created. This prioritising of action in the here-and-now, and vision of creating a better world, parallels the present-tense focus (Melucci 227) of the prefigurative politics in which they were engaged. Mirroring the emphasis upon political values being lived out in everyday life through the alternative lifestyle practices described above, there was also a stress on religious growth being experienced through the "doings" of day-to-day life, and an "actions-speak-louderthan-words" rhetoric. Ash recommended "don't go to church and look for Jesus- just live", his biggest influence being "people, who don't even mention Jesus, that live it". This focus upon "doings" extends to actions being prioritised over the label under which they might be categorised. George, for example, highlighted the capacity of the "secular" Occupy camp "to out-Christian the Christian church" through its actions, demonstrating the view that Christianity, as something livedout, has the capacity to be more authentically expressed by non-Christians than the institutional church. Thus, a focus on "doings" within a largely post-institutional context was a prevalent feature of the Christian Occupiers' political and religious identities, the two becoming significantly merged and interlinked. 


\section{Conclusion}

The term "activist religiosity" has been deployed here to try and bridge the divide between conceptualisations of political identity and religious identity, demonstrating how emerging trends in both religious expression and political organising can be combined and integrated. It thus hopes to move away from social movement theory approaches in which religion is predominantly considered in more instrumental terms as a resource. The work of new social movement theorists, such as Melucci, and other commentators on contemporary politics would suggest that the political characteristics of the Christian Occupiers are not unusual. Similarly, an examination of embryonic scholarship on the Emerging Church, an "unfolding field of thought and practice... populated by a variety of Christian institutions and actors" (Bielo 220), finds many similarities in terms of religious identity. These include; concern with being and doing church rather than attending; preoccupation with authenticity; concentration on following Jesus (Harrold); rejection of denominational structures; left-wing leaning (Hunt 2008); a "post-conservative and post-liberal" identity (Moody 499); an enlarged conception of evangelism, beyond "getting people saved" (Bader-Saye 19); and a shift from orthodoxy to orthopraxis (Marti and Ganiel 134). ${ }^{7}$ However, despite these interesting and useful explorations of contemporary religion and politics, little scholarship has considered how these features may merge to create more integrated religio-political identities, and the term "activist religiosity" has subsequently been offered here as an attempt to do so. Though Occupy's location ${ }^{8}$ outside St Paul's was central in creating opportunities for this identity to be expressed more explicitly, there is significant potential to explore whether other spaces allow for similar articulation of such ways of religio-political being and doing.

\footnotetext{
${ }^{1}$ Symon

${ }^{2}$ Based upon the accounts of four people involved: George, Sam, Siobhan and Symon

${ }^{3}$ Anonymised.

${ }^{4}$ All interviewees' names appear here as they requested. Hereafter, I refer to all by their first name.

${ }^{5}$ The discussion of St Paul's is not complicated by additional reference to Sheffield Cathedral. However, I do draw upon Joe and Ash's religio-political identities.

${ }^{6}$ Accounts vary, but five were named.
} 
${ }^{7}$ Tomlinson's The Post-Evangelical also highlights some of these trends, including church deconversion; dislike of institutions and hierarchies; and increased emphasis on intuition. Gordon Lynch's (2002) consideration of post-evangelicalism in the context of Generation X is also useful. 
Emily Winter is a PhD student at Lancaster University, studying the young adult engagement strategies of Christian social action groups in the UK. She is particularly interested in the interactions between contemporary Christianity and socio-political participation. Correspondence: Emily Winter, c/o Department of Sociology, Bowland North, Lancaster University, Lancaster, LA1 4YN

\section{Acknowledgments}

This article is based on the findings of my MA dissertation and I am very grateful to my supervisors Professor Linda Woodhead and Dr Bronislaw Szerszynski for their guidance and support. I am also indebted to my referees' feedback, which helped me greatly to develop this article. This work was supported by the Economic and Social Research Council [ES/J500094/1].

No potential conflict of interest was reported by the author.

\section{Bibliography}

Ammerman, Nancy. "Spiritual But Not Religious? Beyond Binary Choices in the Study of Religion." Journal for the Scientific Study of Religion 52 (2013): 258-278.

“Observing Religious Modern Lives." Ed. Nancy Ammerman. Everyday Religion: Observing Modern Religious Lives. Oxford: Oxford UP, 2007, 3-18.

Bader-Saye, Scott. "Improvising Church: An Introduction to the Emerging Church Conversation." International Journal for the Study of the Christian Church 6 (2006): 12-23.

BBC. 'Occupy London' start camp in Finsbury Square. 22 Oct. 2011. Web. 9 Sep. 2013. <http://www.bbc.co.uk/news/uk-england-london-15415296>

Bielo, James S. "The 'Emerging Church' in America: Notes on the Interaction of Christianities." Religion 39 (2009): 219-232.

Bobel, Chris. "I'm not an activist though I've done a lot of it': Doing Activism, Being Activist and the Perfect Standard in a Contemporary Movement." Social Movement Studies 6 (2007): 147-159.

Brown, R. Khari. "Religion, Political Discourse and Activism Among Varying Racial/Ethnic Groups in America." Review of Religious Research 53 (2011): 301-322.

Brown, R. Khari, and Robert E. Brown. "Faith and Works: Church-Based Social Capital Resources and African American Political Activism." Social Forces 82 (2003): 617-641.

Bryman, Alan. Social Research Methods- Second Edition. Oxford: Oxford UP, 2004.

Burningham, Kate, and Diana Thrush, D. (2001) 'Exemplar: The Environmental Concerns of Disadvantaged Groups' Ed. Nigel Gilbert. Researching Social Life-Second Edition. London: Sage, 2001, 178-193. 
Butt, Riazat, Shiv Malik, and Lizzy Davies. "St Paul's Cathedral canon resigns." The Guardian. 27 Oct. 2011. Web. 9 Sep. 2013. <http://www.theguardian.com/uk/2011/0ct/27/st-pauls-cathedral-canonresigns>

Campbell, David E. "Acts of Faith: Churches and Political Engagement." Political Behaviour 26 (2004): 155-165.

Castells, Manuel. Networks of Outrage and Hope: Social Movements in the Internet Age. Cambridge: Polity, 2012.

Chatterton, Paul. "So What Does It Mean to be Anti-Capitalist? Conversations with Activists from Urban Social Centres." Urban Studies 47 (2010): 1205-1224.

Davie, Grace. Religion in Britain since 1945: Believing without Belonging. Oxford: Blackwell, 1994. Dinham, Adam, Robert Furbey, and Vivien Lowndes. "Conclusions". Eds. Adam Dinham, Robert Furbey and Vivien Lowndes. Faith in the Public Realm: Controversies, Policies and Practices. Bristol: Policy, 2009, 223-236.

Drane, John. "The Emerging Church." International Journal for the Study of Christian Church 6 (2006): 3-11.

Edles, Laura Desfor. "Contemporary Progressive Christianity and its Symbolic Ramifications." Cultural Sociology 7 (2013): 3-22.

Engelke, Matthew. God's Agents: Biblical Publicity in Contemporary England. Berkeley: U. California P., 2013.

Faver, Catherine A. "To Run and Not Be Weary: Spirituality and Women's Activism". Review of Religious Research 42 (2000): 61-78.

Flory, Richard W., and Donald E. Miller. Finding Faith: The Spiritual Quest of the Post-Boomer Generation. New Brunswick: Rutgers UP, 2008.

Fuller, Robert C. Spiritual, but not Religious: Understanding Unchurched America. Oxford: Oxford UP, 2001.

Guest, Matthew, and Steve Taylor, S. "The Post-Evangelical Emerging Church: Innovation in New Zealand and the UK." International Journal for the Study of the Christian Church 6 (2006): 49-64. Halvorsen, Sam. "Beyond the Network? Occupy London and the Global Movement." Social Movement Studies: Journal of Social, Cultural and Political Protest 11 (2012): 427-433. 
Harris, Elizabeth. (2006) "The Word of the Buddha and Jesus, the Word: Conversion from Christianity to Buddhism and from Buddhism to Christianity." Eds. Christopher Partridge and Helen Reid. Finding and Losing Faith: Studies in Conversion. Milton Keynes: Paternoster, 2006, 39-55. Harrold, Philip. "Reconversion in the Emerging Church." International Journal for the Study of the Christian Church 6 (2006): 79-90.

Hart, Stephen. Cultural Dilemmas of Progressive Politics: Styles of Engagement among Grassroots Activists. Chicago: U. Chicago P., 2001.

Heelas, Paul, and Linda Woodhead. The Spiritual Revolution: Why Religion is Giving Way to Spirituality. London: Blackwell, 2005.

Hunt, Stephen. "The Emerging Church and its Discontents." Journal of Beliefs and Values; Studies in Religion and Education 29 (2008): 287-296

Hutchison, Elizabeth D. "Spirituality, Religion and Progressive Social Movements: Resources and Motivation for Social Change." Journal of Religion and Spirituality in Social Work: Social Thought 31 (2012): 105-127

Independent Catholic News. Interfaith prayers at St Paul's 'Sermon on the Steps. 30 Oct. 2011. Web. 9 Sep. 2013. <http://www.indcatholicnews.com/news.php?viewStory=19206> Jamieson, Alan. Journeying in Faith: In and Beyond the Tough Places. London: SPCK, 2004. Juris, Jeffrey S., Michelle Ronayne, Firuzeh Shokooh-Valle, and Robert Wengronowitz. "Negotiating Power and Difference within the 99\%." Social Movement Studies: Journal of Social, Cultural and Political Protest 11 (2012): 434-440.

Juris, Jeffrey S. Networking Futures: The Movements Against Corporate Globalisation. Durham: Duke UP, 2008.

Knight, Peter. Small-Scale Research: Pragmatic Inquiry in Social Science and the Caring Professions. London: Sage, 2002.

Kong, Lily. "Global Shifts, Theoretical Shifts: Changing Geographies of Religion." Progress in Human Geography 34 (2010): 755-776.

Luckmann, Thomas. "Shrinking Transcendence, Expanding Religion?" Sociological Analysis 51 (1990): 127-138.

Lynch, Gordon. "Exploring the Process of Moving Away from Evangelical Christianity." Ed. Christopher Partridge and Helen Reid. Finding and Losing Faith: Studies in Conversion. Milton Keynes: Paternoster, 2006, 23-38. 
Lynch, Gordon. After Religion: 'Generation X' and the Search for Meaning. London: Darton, Longman \& Todd, 2002.

Lyon, David. Jesus in Disneyland: Religion in Postmodern Times. Cambridge: Polity, 2002.

Marti, Gerardo, and Gladys Ganiel. The Deconstructed Church: Understanding Emerging Christianity. New York: Oxford University, 2014.

McVeigh, Rory, and David Sikkink. "God, Politics and Protest: Religious Beliefs and the Legitimation of Contentious Tactics." Social Forces 79 (2001): 1425-1458.

Melucci, Alberto. Nomads of the Present: Social Movements and Individual Needs in Contemporary Society. London: Hutchinson Radius, 1989.

Moody, Katharine Sarah. "I hate your church: what I want is my kingdom': Emerging Spiritualities in the UK Emerging Church Milieu." The Expository Times 12 (2010): 495-503.

Moritz, Joshua M. "Beyond Strategy, Towards the Kingdom of God: The Post-Critical Reconstructionist Mission of the Emerging Church." Dialog: A Journal of Theology 47 (2008): 27-37. Murray, Stuart. Post-Christendom. Milton Keynes: Paternoster, 2004.

Occupy Faith. Occupy Faith UK-Speaking Truth to Power. Mar. 19 2012. Web. 9 Sep.2013.

$<$ http://occupyfaith.org.uk/?p=46> [

Occupy London. About Occupy London. 2012. Web. 9 Sep. 2013. <http://occupylondon.org.uk/ about/>

Occupy the London Stock Exchange. Christian Solidarity with the 'Occupy London' Movement. 24 Oct. 2011. Web. 9 Sep. 2013. < http://occupylsx.org/?p=388>

Pickerill, Jenny, and John Krinsky, J. "Why does Occupy matter?" Social Movement Studies: Journal of Social, Cultural and Political Protest 11 (2012): 279-287.

Poonamallee, Latha. "Transforming Realities- Making the Improbable Possible: Reclaiming of Sacredness as a Source of Generative Capacities." Journal of Management Inquiry 20 (2011): 242-262. Smith, Christian. Disruptive Religion: The Force of Faith in Social Movement Activism. New York: Routledge, 1996.

Stanczak, Gregory C. Engaged Spirituality: Social Change and American Religion. New Brunswick: Rutgers UP, 2006.

Swarts, Heidi. Organising Urban America: Secular and Faith-Based Progressive Movements. Minnesota: U. Minnesota P., 2008. 
Szerszynski, Bronislaw. "The Varieties of Ecological Piety." Worldviews: Environment, Culture, Religion 1 (1997): 37-55.

Taylor, Astra, and Keith Gessen, eds. Occupy! Scenes from Occupied America, London: Verso , 2011.

Taylor, Charles. The Ethics of Authenticity. Cambridge MA: Harvard UP, 1992.

Taylor, Jerome. "Police letter reveals St Paul's cathedral involvement in Occupy eviction." The Independent. 25 May 2012. Web. 9 Sep. 2013. <http://www.independent.co.uk/news/uk/homenews/police-letter-reveals-st-pauls-cathedral-involvement-in-occupy-eviction-7788730.html>

Todd, Nathan. "Religious Networking Organisations and Social Justice: An Ethnographic Case Study." American Journal of Community Psychology 50 (2012): 229-245.

Tomlinson, Dave. The Post-Evangelical. London: Triangle, 1995.

Wald, Kenneth D., Adam L. Silverman, and Kevin S. Fridy. "Making Sense of Religion in Political Life." Annual Review of Political Science 8 (2005): 121-143

Williams, Rhys. "Religious Social Movements in the Public Sphere: Organisation, Ideology and Activism." Ed. Michele Dillon. Handbook of the Sociology of Religion. Cambridge: Cambridge UP, 2003, 315-330.

\footnotetext{
“From the 'Beloved Community' to 'Family Values': Religious Language, Symbolic Repertoires and Democratic Culture." Eds. David S. Meyer, Nancy Whittier, and Belinda Robnett. Social Movements: Identity, Culture and the State, Oxford: Oxford UP, 2002, 247-265.
}

Wood, Richard. "Religion, Faith-Based Community Organising and the Struggle for Justice." Ed. Michele. Dillon. Handbook of the Sociology of Religion. Cambridge: Cambridge UP, 2003, 385-399.

Wuthnow, Robert. "The Cultural Turn: Stories, Logic, and the Quest for Identity in American Religion." Eds. Penny Egdell Becker and Nancy L. Eiesland. Contemporary American Religion: An Ethnographic Reader. London: AltaMira, 1997, 245-265. 